\title{
Estimation of Radioactivity and Associated Radiological Hazards of Cement Used in Sri Lanka
}

\section{Deepa Ranjanie Abeydeera ${ }^{*}$, Rohini Hewamanna, Mahendra Prinath Dias ${ }^{3}$, Palee Mahawatta 4}

${ }^{1}$ Department of Physics, The Open University, Nawala, Sri Lanka

${ }^{2,4}$ Department of Nuclear Science, University of Colombo, Colombo 3, Sri Lanka

${ }^{3}$ Department of Electrical Engineering, University of Moratuwa, Moratuwa, Sri Lanka

\section{Abstract}

Cement used in construction work can cause internal and external radiation exposure due to the presence of natural radionuclides ${ }^{226} \mathrm{Ra},{ }^{232} \mathrm{Th}$ and ${ }^{40} \mathrm{~K}$. The radiation exposure risk can be estimated by finding the indoor absorbed dose rate and the annual effective dose. If the annual effective dose is within the internationally accepted value, use of cement can be considered safe and the risk will be within acceptable levels. The specific activities of ${ }^{226} \mathrm{Ra},{ }^{232} \mathrm{Th}$ and ${ }^{40} \mathrm{~K}$ in 85 samples from eleven types of cement were measured using gamma spectroscopy with a HPGe detector and the annual effective dose was calculated to determine the radiological hazard from the natural radioactivity in the samples. The average specific activities measured in $\mathrm{Bq} \mathrm{kg}^{-1}$ ranged from $21.4 \pm 0.9$ to $66.8 \pm 1.2$ $; 13.8 \pm 0.9$ to $62.1 \pm 2.3$ and $83.7 \pm 4.9$ to $239.9 \pm 5.7$ for ${ }^{226} \mathrm{Ra},{ }^{232} \mathrm{Th}$ and ${ }^{40} \mathrm{~K}$ respectively.

* Correspondence should be addressed to Ms. D. R. Abeydeera.

Email:drabe@ou.ac.lk

https:/ / orcid.org/0000-0002-0753-3913

(Received $2^{\text {nd }}$ April 2018; Revised 22nd May 2018; Accepted 08th June 2018) C OUSL

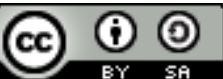

This article is published under the Creative Commons Attribution-Share Alike 4.0 International License (CC-BY-SA). This license permits use, distribution and reproduction in any medium; provided it is licensed under the same terms and the original work is properly cited. 
The highest activity of both ${ }^{226} \mathrm{Ra}$ and ${ }^{232} \mathrm{Th}$ were obtained in CEM III- PPC 1 cement which contains $25 \%$ fly ash from a coal power plant. The lowest activities of ${ }^{226} \mathrm{Ra},{ }^{40} \mathrm{~K}$ and ${ }^{232} \mathrm{Th}$ were observed in CEM-X imported OPC 3 cement. It was observed that for all the studied cement samples the annual effective dose ranged from 0.15 to $0.51 \mathrm{mSv} \mathrm{y}^{-1}$.and less than the recommended maximum permissible public dose $1.0 \mathrm{mSv}^{-1}$. The results obtained in this study indicate that there is no radiological hazard arising from the use of the studied cement varieties in building construction.

Keywords: building construction, cement, equivalent dose, radiological hazard, radionuclides,

\section{Introduction:}

All building materials, such as bricks, sand and cement derived from rocks and soil contain naturally occurring radionuclides of uranium $\left({ }^{238} \mathrm{U}\right)$ and thorium $\left.{ }^{232} \mathrm{Th}\right)$ series and the radioactive isotope of potassium $\left({ }^{40} \mathrm{~K}\right)$. These radionuclides are also present in raw materials used in making cement, such as limestone, gypsum and fly ash. Radium $\left({ }^{226} \mathrm{Ra}\right)$ which is a member of the ${ }^{238} \mathrm{U}$ decay series is the most important isotope radiologically since radium and its daughter products produce $98.5 \%$ of the radiological effects of the uranium series. Therefore, the contribution from $238 \mathrm{U}$ can be considered as that of ${ }^{226} \mathrm{Ra}$ and its daughter products. The radiation exposure from building materials due to these radionuclides is due to both internal and external exposures. The external exposure is caused by direct gamma radiation from an external source. The internal exposure is caused by the inhalation of the gaseous daughter products radon $\left({ }^{222} \mathrm{Rn}\right)$ and thoron $\left({ }^{220} \mathrm{Rn}\right)$ and their shortlived secondary decay products. Cement is used as a construction material for houses and other buildings in Sri Lanka. It is also used to make cement blocks and concrete as well as for plastering walls of houses and buildings. The demand for cement in Sri Lanka is increasing as a result of the increasing population and the expansion of infrastructure. Fly ash from coal power plants is used as a raw material in the manufacture of some brands of cement.

The aim of this study was to determine the specific activities of 226Ra, ${ }^{232} \mathrm{Th}$ and ${ }^{40} \mathrm{~K}$ in different brands of cement and in the raw materials used to manufacture cement and to assess the associated 
radiological hazard from the use of cement. Cement samples were analyzed using high-resolution gamma spectrometry.

The potential radiological hazard was determined by computing the annual effective dose. The specific activities of ${ }^{226} \mathrm{Ra},{ }^{232} \mathrm{Th}$ and ${ }^{40} \mathrm{~K}$ in Sri Lankan made cement were compared with the corresponding value of cement manufactured in some other countries.

The specific activities of $226 \mathrm{Ra},{ }^{232} \mathrm{Th}$ and ${ }^{40} \mathrm{~K}$ were also measured for raw materials of cement such as fly ash, gypsum, limestone, dolomite and clinker.

\section{Materials \& Methods}

\section{Sampling and sample preparation}

A total of 85 cement samples manufactured in 2013 and 2014, from 11 main brands used in Sri Lanka were collected from the local market and from a cement factory. The types of cement and the proportions of raw materials in cement products are shown in Table 1 .

Table 1: Brands of cement samples and the proportions of raw materials

\begin{tabular}{|c|c|c|c|c|c|}
\hline $\begin{array}{l}\text { Type of } \\
\text { cement }\end{array}$ & $\begin{array}{l}\text { No. of } \\
\text { Samp- } \\
\text { les }\end{array}$ & $\begin{array}{l}\text { Clink } \\
\text { er } \\
(\%)\end{array}$ & $\begin{array}{l}\text { Lime- } \\
\text { stone } \\
(\%)\end{array}$ & $\begin{array}{l}\text { Fly } \\
\text { ash } \\
(\%)\end{array}$ & $\begin{array}{c}\text { Minor } \\
\text { constituents } \\
(\%)\end{array}$ \\
\hline CEM-I-OPC 1 & 10 & $\begin{array}{l}95- \\
100\end{array}$ & - & - & $\begin{array}{l}\text { O- } \\
\text { 5(Gypsum/Dolomit } \\
\text { e) }\end{array}$ \\
\hline CEM-II-PLC & 10 & $80-94$ & $6-20$ & 1 & $\begin{array}{l}\text { 0- } \\
\text { 5(Gypsum/Dolomit } \\
\text { e) }\end{array}$ \\
\hline CEM-III-PPC 1 & 10 & 70 & - & 25 & 5 (Gypsum) \\
\hline CEM-IV-OPC 2 & 5 & 91 & - & 5 & 4 (Gypsum) \\
\hline CEM-V-OPC 3 & 5 & 94 & - & 2 & 4 (Gypsum) \\
\hline CEM-VI-PPC 2 & 20 & 75 & - & 20 & 5 (Gypsum) \\
\hline $\begin{array}{l}\text { CEM-VII-OPC } \\
4\end{array}$ & 5 & $\begin{array}{l}95- \\
100\end{array}$ & - & - & $\begin{array}{l}\text { 0- } \\
\text { 5(Gypsum/Dolomit }\end{array}$ \\
\hline $\begin{array}{l}\text { CEM-VIII } \\
\text { Imported OPC } \\
1\end{array}$ & 5 & $\begin{array}{l}95- \\
100\end{array}$ & - & - & $\begin{array}{l}\text { 0- } \\
\text { 5(Gypsum/Dolomit } \\
\text { e) }\end{array}$ \\
\hline
\end{tabular}




\begin{tabular}{|c|c|c|c|c|c|}
\hline $\begin{array}{l}\text { CEM-IX } \\
\text { Imported OPC } \\
2\end{array}$ & 5 & $\begin{array}{c}95- \\
100\end{array}$ & - & - & $\begin{array}{l}\text { 0- } \\
\text { 5(Gypsum/Dolomit } \\
\text { e) }\end{array}$ \\
\hline $\begin{array}{l}\text { CEM-X } \\
\text { Imported OPC } \\
3\end{array}$ & 5 & $\begin{array}{c}95- \\
100\end{array}$ & - & - & $\begin{array}{l}\text { 0- } \\
5 \text { (Gypsum/Dolomit } \\
\text { e) }\end{array}$ \\
\hline $\begin{array}{l}\text { CEM-XI } \\
\text { Imported PPC } \\
1\end{array}$ & 5 & $65-89$ & - & $11-35$ & $\begin{array}{l}\text { 0- } \\
\text { 5(Gypsum/Dolomit } \\
\text { e) }\end{array}$ \\
\hline
\end{tabular}

(OPC-Ordinary Portland Cement, PLC-Portland Limestone Cement, PPC-Portland Pozzolana Cement)

Thirty samples of raw materials were also collected from a cement factory. (Five samples each of limestone, dolomite, clinker, gypsum and 10 samples of fly ash).

The cement samples were dried in a temperature-controlled furnace for 14 hours at $110^{\circ} \mathrm{C}$ to remove moisture. These samples were not sieved as the particles were very fine.

Some raw materials, such as clinker, dolomite and limestone were initially broken into small parts by using a hammer, milled using a grinder and sieved by a sieve of mesh size $250 \mu \mathrm{m}$. Fly ash samples were not sieved as they were already in powdered form. Gypsum samples were also sieved using a $250 \mu \mathrm{m}$ mesh size without grinding. All raw material samples were oven dried at $110{ }^{\circ} \mathrm{C}$ for $14-21$ hours to remove moisture.

Dried homogeneous samples of cement and raw materials of cement were thereafter sealed tightly in plastic containers (diameter $8.0 \mathrm{~cm}$ and height $2.5 \mathrm{~cm}$ ) and kept for 30 days until radioactive equilibrium was reached.

\section{Measurement of specific radioactivity}

The specific activities of the radionuclides were determined by high resolution gamma spectrometry using a HPGe (Hyper Pure Germanium) detector with a relative efficiency of $20.6 \%$ and an energy resolution of $1.85 \mathrm{keV}$ FWHM (full width at half-maximum) for the $1332 \mathrm{keV}$ gamma ray line of ${ }^{60} \mathrm{Co}$. GENIE 2000 software was used to analyze the spectra. The high resolution HPGe gamma spectrometry system consists of a p-type intrinsic Germanium co- 
axial detector (type: EG and ORTEC model GEM 13200) mounted vertically and coupled to a multi-channel analyser. (Canberra S100 MCA, with 4023 channels). The detector was mounted in a cylindrical lead shield with a thickness of $10 \mathrm{~cm}$ to reduce the effect of background radiation.

The spectrometer was calibrated for energy and efficiency over the photon energy range of $186 \mathrm{keV}$ - $2700 \mathrm{keV}$ using IAEA reference materials, RGU-1 (U-ore), RGTh-1 (Th-ore) and RGk-1 ( $\left.\mathrm{K}_{2} \mathrm{SO}_{4}\right)$, packed in containers whose geometry was identical to that of the geometry of cement and raw material samples. The accumulation time for gamma ray spectra ranged between 61,200 and 64,800 seconds, sufficient for a statistical error of less than 1\%. Background measurements were also taken over the same period of time. For all samples, the ${ }^{226} \mathrm{Ra}$ specific activity was measured from the gamma ray line of $351.9 \mathrm{keV}$ (37.1\%) from ${ }^{214} \mathrm{~Pb}$ and 609.3 (46.1\%), 1120.2 (15.1\%) and 1764.5 (15.9\%) keV lines from ${ }^{214} \mathrm{Bi}$. The specific activity of $232 \mathrm{Th}$ was determined from 583.1 (86\%) and $2614 \mathrm{keV}$ gamma lines of $208 \mathrm{Tl}, 238.6$ (43.6\%) keV line from ${ }^{212} \mathrm{~Pb}$ and $338.4(12 \%)$ and 911.1 (29\%) keV lines from 228Ac. The $40 \mathrm{~K}$ concentration was calculated from its $1460.8 \mathrm{keV}$ gamma line. The values inside the parentheses are the absolute probabilities of the gamma decay.

\section{Estimation of specific activity}

The activities of radionuclides in the samples were computed using equation (1). The specific activities in $\mathrm{Bq} \mathrm{kg}^{-1}$ of the radionuclides were calculated by dividing the activity by the mass of the dried samples expressed in kilogram using equation (2).

The activity $A$ and specific activity $A_{s p}$ are given by,

$$
\begin{aligned}
& A=\frac{Z}{r \epsilon t} \\
& A_{\mathrm{sp}}=\frac{A}{M}=\frac{Z}{M r \epsilon t}
\end{aligned}
$$

Where, $Z$ is the background subtracted counts under the photopeak, $r$ - the gamma emission probability, $t$-the counting time of samples and $\epsilon$ the photopeak efficiency for the corresponding gamma energy and $M$ the dry mass of the sample.

The photopeak efficiency $\in$ was calculated using equation (3), 


$$
\epsilon=\frac{Z^{\prime}}{r A_{s t} t^{\prime}}
$$

Where, $A_{s t}$ - Activity of the IAEA reference material (RGU), $t^{\prime}$ counting time of the reference material, $r$ - gamma emission probability, $Z^{\prime}$ - the background subtracted count under the photopeak for the reference material.

\section{Estimation of Uncertainty of Specific Activity}

The uncertainty of the specific activity depends on the uncertainty of the measured parameters, namely the count-rate, the efficiency of the detector and the mass of the sample.

$$
A_{s p}=\frac{Z}{M r \epsilon t}=\frac{C}{M r \epsilon}
$$

Where, $c=\frac{Z}{t}$ is the count-rate.

It can be shown that the most probable error of the specific activities can be expressed by the equation 5 (Topping, 1972).

$$
\left(\delta A_{s p}\right)^{2}=A_{s p}^{2}\left\{\left(\frac{\delta C}{C}\right)^{2}+\left(\frac{\delta \epsilon}{\epsilon}\right)^{2}+\left(\frac{\delta r}{r}\right)^{2}+\left(\frac{\delta M}{M}\right)^{2}\right\}
$$

Where, $\delta A_{s p}$ - The uncertainty of the specific activity, $\delta c$ - The uncertainty of the count-rate, $\delta r$ - The uncertainty of gamma emission probability, $\delta \epsilon-$ The uncertainty of the efficiency, $\delta M-$ The uncertainty of the measurement of mass.

\section{Estimation of Minimum Detectable Activity (MDA)}

The MDA is a measure of the lowest level at which sample activity can be distinguished from the background. The minimum detectable activity (MDA) of the gamma spectroscopic system was calculated using the equation (6) (Curie, 1968).

$$
\mathrm{MDA}=\frac{k \alpha \sigma}{\epsilon r t M}\left(\mathrm{~Bq} \mathrm{~kg}^{-1}\right)
$$

Where, $\sigma$ - The standard deviation of the background in the region of interest which is the square root of the number of counts of the 
spectrum in a given time, since it has a Poisson distribution, and $k \alpha$ -The statistical coverage factors equal to 1.645 at $95 \%$ confidence level.

\section{Assessment of the radiation hazard}

In this study, the indoor annual effective dose was determined to assess the potential radiation hazard.

\section{The Annual Effective Dose Rate (A.E.D.)}

The indoor annual effective dose due to the gamma ray emission from the radionuclides ${ }^{226} \mathrm{Ra},{ }^{232} \mathrm{Th}$ and ${ }^{40} \mathrm{~K}$ in cement used as a building material to construct a reference room with dimensions 6 $\mathrm{m} \times 4 \mathrm{~m} \times 3 \mathrm{~m}$ can be calculated from the Equation 7 given below (Interim report, The Netherlands, 1985). It is assumed that the ceiling, walls and the floor of the room are made of concrete with density $2400 \mathrm{~kg} \mathrm{~m}^{-3}$ and thickness $12 \mathrm{~cm}$.

$$
\text { A.E.D. }=D t T F
$$

Where, $D$ - Absorbed dose rate in air $\mathrm{mGy} \mathrm{h}^{-1}, t$ - the number of hours in a year $=8760 \mathrm{~h} \mathrm{y}^{-1}, F$ - Conversion factor of absorbed dose in air to effective dose $=0.7\left(\mathrm{~Sv} \mathrm{~Gy}^{-1}\right), T=$ The indoor occupancy factor.

External exposure to gamma radiation from natural radioactive elements occurs both indoors and outdoors. For calculation of annual dose it is important to take into account the occupancy factor. Here it is assumed that people spend $20 \%$ of their time outdoors and $80 \%$ indoors on an average worldwide (UNSCEAR, 2008). Hence the indoor occupancy factor $T$ is taken as 0.8 .

The absorbed dose rate $(D)$ can be expressed as a sum of contributions from the different radionuclides in the building material (Equation 8).

$$
D=q_{R a} C_{R a}+q_{T h} C_{T h}+q_{k} C_{k}
$$

Where, $C_{R a}, C_{T h}$ and $C_{K}$ are the specific activities in Bq kg-1 of $226 \mathrm{Ra}$, ${ }^{232} \mathrm{Th}$ and ${ }^{40} \mathrm{~K}$ respectively, $q_{R a}, q_{T h}, q_{k}$ are the factors for converting the radioactivity concentrations in a building material to the 
absorbed dose rate in air and at $1 \mathrm{~m}$ distance away from the surface of the material (Interim report, The Netherlands, 1985).

$$
\begin{aligned}
& q_{R a}=620 \times 10^{-9} \mathrm{mGy} \mathrm{h}^{-1} / \mathrm{Bq} \mathrm{kg}^{-1} \\
& q_{T h}=890 \times 10^{-9} \mathrm{mGy} \mathrm{h}^{-1} / \mathrm{Bq} \mathrm{kg}^{-1} \\
& q_{k}=54 \times 10^{-9} \mathrm{mGy} \mathrm{h}^{-1} / \mathrm{Bq} \mathrm{kg}^{-1}
\end{aligned}
$$

\section{Results and Discussion}

\section{Specific activity}

The specific activities of ${ }^{226} \mathrm{Ra},{ }^{232} \mathrm{Th}$ and ${ }^{40} \mathrm{~K}$ were determined for all the studied cement samples and raw materials of cement. The mean specific activity values of these radionuclides with the statistical uncertainty are presented in Table 2 and Table 3 respectively. These results are also shown graphically in Figure 1 and Figures 2, 3 and 4.

Table 2: The range and the mean specific activities with uncertainty

\begin{tabular}{|c|c|c|c|c|}
\hline $\begin{array}{l}\text { Type of } \\
\text { Cement }\end{array}$ & & $\begin{array}{c}{ }^{226} \mathrm{Ra}(\mathrm{Bq} \\
\left.\mathrm{kg}^{-1}\right)\end{array}$ & $\begin{array}{c}{ }^{232} \mathrm{Th}(\mathrm{Bq} \\
\left.\mathrm{kg}^{-1}\right)\end{array}$ & ${ }^{40} \mathrm{~K}\left(\mathrm{~Bq} \mathrm{~kg}^{-1}\right)$ \\
\hline \multirow[t]{3}{*}{ CEM-1 OPC 1} & Mean & $\begin{array}{r}27.9 \pm \\
0.7\end{array}$ & $25.1 \pm 0.9$ & $99.5 \pm 4.2$ \\
\hline & Max. & $\begin{array}{r}33.7 \pm \\
2.3\end{array}$ & $29.4 \pm 3.5$ & $\begin{array}{r}126.6 \pm \\
13.6\end{array}$ \\
\hline & Min. & $\begin{array}{r}20.8 \pm \\
2.0\end{array}$ & $18.7 \pm 2.6$ & $\begin{array}{r}50.6 \pm \\
13.3\end{array}$ \\
\hline \multirow[t]{3}{*}{ CEM-II PLC } & Mean & $\begin{array}{r}26.5 \pm \\
0.6\end{array}$ & $23.4 \pm 0.8$ & $\begin{array}{r}93.3 \pm \\
3.5\end{array}$ \\
\hline & Max. & $\begin{array}{r}29.5 \pm \\
1.9\end{array}$ & $26.2 \pm 2.9$ & $\begin{array}{r}103.9 \pm \\
11.9\end{array}$ \\
\hline & Min. & $\begin{array}{r}22.8 \pm \\
1.9\end{array}$ & $20.9 \pm 2.6$ & $\begin{array}{r}62.5 \pm \\
10.5\end{array}$ \\
\hline $\begin{array}{l}\text { CEM-III PPC } \\
1\end{array}$ & Mean & $\begin{array}{r}66.8 \pm \\
1.2\end{array}$ & $62.1 \pm 2.3$ & $\begin{array}{r}131.5 \pm \\
5.9\end{array}$ \\
\hline
\end{tabular}
of ${ }^{226} \mathrm{Ra},{ }^{232} \mathrm{Th}$ and ${ }^{40} \mathrm{~K}$ of all types of cement samples in $\mathrm{Bq} \mathrm{kg}^{-1}$ 


\begin{tabular}{|c|c|c|c|c|}
\hline & Max. & $\begin{array}{r}71.3 \pm \\
2.8\end{array}$ & $68.9 \pm 6.3$ & $\begin{array}{r}168.3 \pm \\
14.6\end{array}$ \\
\hline & Min. & $\begin{array}{r}62.7 \pm \\
2.9\end{array}$ & $57.7 \pm 5.7$ & $\begin{array}{r}103.2 \pm \\
13.1\end{array}$ \\
\hline \multirow[t]{3}{*}{$\begin{array}{l}\text { CEM-IV OPC } \\
2\end{array}$} & Mean & $\begin{array}{r}44.9 \pm \\
0.9\end{array}$ & $23.0 \pm 1.3$ & $\begin{array}{r}226.4 \pm \\
6.7\end{array}$ \\
\hline & Max. & $\begin{array}{r}46.2 \pm \\
2.2\end{array}$ & $26.7 \pm 3.1$ & $\begin{array}{r}240.5 \pm \\
14.9\end{array}$ \\
\hline & Min. & $\begin{array}{r}42.4 \pm \\
2.2\end{array}$ & $19.4 \pm 2.4$ & $\begin{array}{r}209.3 \pm \\
15.2\end{array}$ \\
\hline \multirow[t]{3}{*}{ CEM-V OPC 3} & Mean & $\begin{array}{r}23.1 \pm \\
0.8\end{array}$ & $28.8 \pm 1.2$ & $\begin{array}{r}239.9 \pm \\
5.7\end{array}$ \\
\hline & Max. & $\begin{array}{r}25.5 \pm \\
1.9\end{array}$ & $31.7 \pm 2.9$ & $\begin{array}{r}258.5 \pm \\
12.5\end{array}$ \\
\hline & Min. & $\begin{array}{r}19.9 \pm \\
1.9\end{array}$ & $26.3 \pm 2.4$ & $\begin{array}{r}224.4 \pm \\
12.3\end{array}$ \\
\hline \multirow[t]{3}{*}{$\begin{array}{l}\text { CEM-VI PPC } \\
2\end{array}$} & Mean & $\begin{array}{r}32.4 \pm \\
0.7\end{array}$ & $32.8 \pm 1.2$ & $\begin{array}{r}179.5 \pm \\
3.8\end{array}$ \\
\hline & Max. & $\begin{array}{r}52.9 \pm \\
2.6\end{array}$ & $43.0 \pm 3.6$ & $\begin{array}{r}220.1 \pm \\
11.6\end{array}$ \\
\hline & Min. & $18.7 \pm 0.9$ & $20.4 \pm 2.2$ & $\begin{array}{r}158.5 \pm \\
12.5\end{array}$ \\
\hline \multirow[t]{3}{*}{$\begin{array}{l}\text { CEM-VII OPC } \\
4\end{array}$} & Mean & $\begin{array}{r}47.5 \pm \\
0.9\end{array}$ & $22.8 \pm 1.2$ & $\begin{array}{r}185.5 \pm \\
5.3\end{array}$ \\
\hline & Max. & $\begin{array}{r}49.0 \pm \\
2.1 \\
\end{array}$ & $24.5 \pm 2.6$ & $\begin{array}{r}197.8 \pm \\
11.4 \\
\end{array}$ \\
\hline & Min. & $\begin{array}{r}46.5 \pm \\
2.1\end{array}$ & $21.0 \pm 2.6$ & $\begin{array}{r}174.1 \pm \\
11.6\end{array}$ \\
\hline \multirow{3}{*}{$\begin{array}{l}\text { CEM-VIII } \\
\text { Imported } \\
\text { OPC } 1\end{array}$} & Mean & $\begin{array}{r}29.1 \pm \\
0.9\end{array}$ & $20.6 \pm 1.1$ & $\begin{array}{r}102.8 \pm \\
4.9\end{array}$ \\
\hline & Max. & $\begin{array}{r}29.8 \pm \\
2.1 \\
\end{array}$ & $25.0 \pm 2.5$ & $\begin{array}{r}110.8 \pm \\
10.6\end{array}$ \\
\hline & Min. & $\begin{array}{r}28.6 \pm \\
10\end{array}$ & $18.8 \pm 2.3$ & $\begin{array}{r}82.4 \pm \\
11\end{array}$ \\
\hline \multirow{3}{*}{$\begin{array}{l}\text { CEM-IX } \\
\text { Imported OPC } \\
2\end{array}$} & Mean & $\begin{array}{r}40.9 \pm \\
0.9\end{array}$ & $25.7 \pm 2.1$ & $\begin{array}{r}195.2 \pm \\
5.6\end{array}$ \\
\hline & Max. & $\begin{array}{r}44.2 \pm \\
2.2 \\
\end{array}$ & $28.4 \pm 3.2$ & $\begin{array}{r}218.4 \pm \\
12.5\end{array}$ \\
\hline & Min. & $\begin{array}{r}38.6 \pm \\
2.1\end{array}$ & $24.1 \pm 2.6$ & $\begin{array}{r}174.6 \pm \\
12.5\end{array}$ \\
\hline
\end{tabular}




\begin{tabular}{|l|l|r|r|r|}
\hline CEM-X & Mean & $21.4 \pm$ & $13.8 \pm 0.9$ & $83.7 \pm 4.9$ \\
\multirow{3}{*}{3} & & 0.9 & & \\
\cline { 2 - 5 } & Max. & $23.5 \pm$ & $15.6 \pm 1.8$ & $102.2 \pm$ \\
& & 1.8 & & 10.4 \\
\cline { 2 - 5 } & Min. & $19.5 \pm$ & $12.5 \pm 1.8$ & $72.9 \pm$ \\
\hline \multirow{2}{*}{$\begin{array}{l}\text { CEM-XI } \\
1\end{array}$} & Mean & $55.9 \pm$ & $41.4 \pm 1.8$ & 10.8 \\
& & 1.1 & & $152.3 \pm$ \\
& Max. & $56.6 \pm$ & $43.2 \pm 4.3$ & $159.7 \pm$ \\
& & 2.1 & & 13.6 \\
\cline { 2 - 5 } & Min. & $54.1 \pm$ & $39.6 \pm 3.9$ & $138.3 \pm$ \\
& & 2.1 & & 1.0 \\
\hline
\end{tabular}

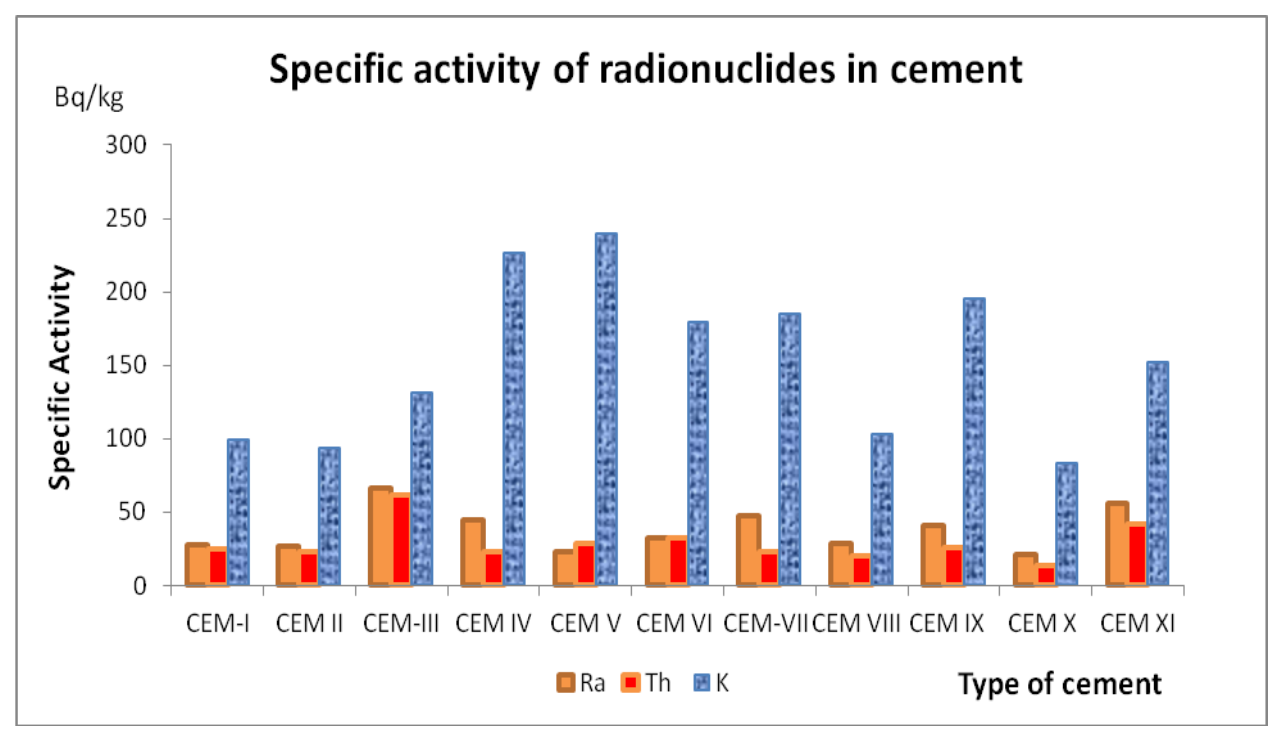

Figure 1: Mean Specific activities of radionuclides in cement samples

As can be seen from Table 2 and Figure 1 the specific activities of 226Ra and ${ }^{232} \mathrm{Th}$ were maximum in CEM-III PPC 1 cement. The specific activity of ${ }^{226} \mathrm{Ra}$ was found in the range $21.4 \pm 0.9$ to $66.8 \pm$ $1.2 \mathrm{~Bq} \mathrm{~kg}^{-1}$ for all cement samples. For ${ }^{232} \mathrm{Th}$ it was found in the range $13.8 \pm 0.9$ to $62.1 \pm 2.3 \mathrm{~Bq} \mathrm{~kg}^{-1}$. The lowest value for ${ }^{226} \mathrm{Ra}$ and ${ }^{232} \mathrm{Th}$ were observed in CEM-X imported OPC 3 cement.

In the case of $40 \mathrm{~K}$, the CEM-V OPC 3 cement samples showed the highest concentration, whereas, CEM-X imported OPC 3 cement samples showed the lowest concentration. The highest and the 
lowest concentrations were $239.9 \pm 5.7 \mathrm{~Bq} \mathrm{~kg}^{-1}$ and $83.7 \pm 4.9 \mathrm{~Bq} \mathrm{~kg}-$ 1 respectively.

According to the results shown in Table 3 and Figures 2, 3 and 4 the concentrations of ${ }^{226} \mathrm{Ra},{ }^{232} \mathrm{Th}$ and ${ }^{40} \mathrm{~K}$ in fly ash are much higher than that of the other raw materials. About $25 \%$ and $20 \%$ fly ash is added to CEM-III PPC 1 cement and CEM-VI PPC 2 cement respectively during manufacturing. About $5 \%$ of fly ash is added to CEM-IV OPC 2 cement and about $2 \%$ of fly ash is added to CEM-V OPC 3 . The reason for the highest specific activities of $226 \mathrm{Ra}$ and ${ }^{232} \mathrm{Th}$ in the CEM-III PPC 1 cement is that it contains $25 \%$ of fly ash produced by combustion of coal. The power plant uses different types of coal and had used Indonesian coal during the period of samples of this brand of cement were collected.

CEM-IV OPC 2 cement samples were collected in June 2013. During this period the power plant used a mixture of South African and Indonesian coal. The specific activities of radionuclides in fly ash emitted during combustion of the mixture of South African and Indonesian coal was higher than what was produced from Indonesian coal. Therefore, a higher concentration of $226 \mathrm{Ra}$ was found in CEM- IV OPC 2 cement than some other local brands of cement.

The worldwide average specific activities of $226 \mathrm{Ra},{ }^{232} \mathrm{Th}$ and ${ }^{40} \mathrm{~K}$ in the Earth's crust were estimated as 32, 45 and $412 \mathrm{~Bq} \mathrm{~kg}-1$ respectively (UNSCEAR, 2008). In all the studied cement samples except in CEM-III PPC 1 the specific activities of ${ }^{232} \mathrm{Th}$ were below the world average value. For all cement samples, the specific activity of $40 \mathrm{~K}$ was below the world average value. As can be seen in Table 2 the specific activity of ${ }^{226} \mathrm{Ra}$ in some brands of cement were higher than the world average value of $32 \mathrm{~Bq} \mathrm{~kg}^{-1}$.

Table 3 shows the mean specific activities of ${ }^{226} \mathrm{Ra},{ }^{232} \mathrm{Th}$ and ${ }^{40} \mathrm{~K}$ in $\mathrm{Bq} \mathrm{kg}^{-1}$, for the raw material samples, clinker, gypsum, dolomite and limestone collected from a cement factory. 
Table 3: Mean specific activities with uncertainty of ${ }^{226} \mathrm{Ra},{ }^{232} \mathrm{Th}$ and $40 \mathrm{~K}$ for the raw materials used in cement samples.

\begin{tabular}{|l|c|c|c|}
\hline $\begin{array}{c}\text { Type of raw } \\
\text { material }\end{array}$ & ${ }^{226} \mathrm{Ra}\left(\mathrm{Bq} \mathrm{kg}^{-1}\right)$ & 232Th $\left(\mathrm{Bq} \mathrm{kg}^{-1}\right)$ & $40 \mathrm{~K}\left(\mathrm{~Bq} \mathrm{~kg}^{-1}\right)$ \\
\hline${ }^{*}$ Fly ash-1 & $73.9 \pm 1.7$ & $71.7 \pm 4.9$ & $357.4 \pm 10.7$ \\
\hline *Fly ash-2 & $63.4 \pm 1.9$ & $66.9 \pm 3.4$ & $189.9 \pm 10.2$ \\
\hline *Fly ash-3 & $144.7 \pm 1.6$ & $115.9 \pm 1.5$ & $422.2 \pm 7.6$ \\
\hline Clinker & $27.5 \pm 0.8$ & $30.5 \pm 1.3$ & $64.9 \pm 4.2$ \\
\hline Gypsum & $1.6 \pm 0.2$ & $2.2 \pm 0.3$ & $21.4 \pm 2.7$ \\
\hline Limestone & $11.4 \pm 0.9$ & $12.2 \pm 0.9$ & $38.7 \pm 5.1$ \\
\hline Dolomite & $2.8 \pm 0.5$ & $0.6 \pm 0.0$ & $1.62 \pm 0.1$ \\
\hline
\end{tabular}

${ }^{*}$ Fly ash-1 (fly ash emitted from burnt Indonesian coal)

*Fly ash-2 (fly ash emitted from burnt mixture of Indonesian and South-African coal)

*Fly ash-3 (fly ash emitted from burnt mixture of South-African and Russian coal)

The specific activities of radionuclides were significantly higher in fly ash than the other raw materials. The specific activities of ${ }^{226} \mathrm{Ra}$ and 232Th in raw materials other than fly ash were lower than the world average of $50 \mathrm{~Bq} \mathrm{~kg}^{-1}$ for building materials (UNSCEAR, 1993). It was observed that for all raw materials the specific activity of $40 \mathrm{~K}$ was less than the world average value of $500 \mathrm{~Bq} \mathrm{~kg}^{-1}$ (UNSCEAR, 1993). 


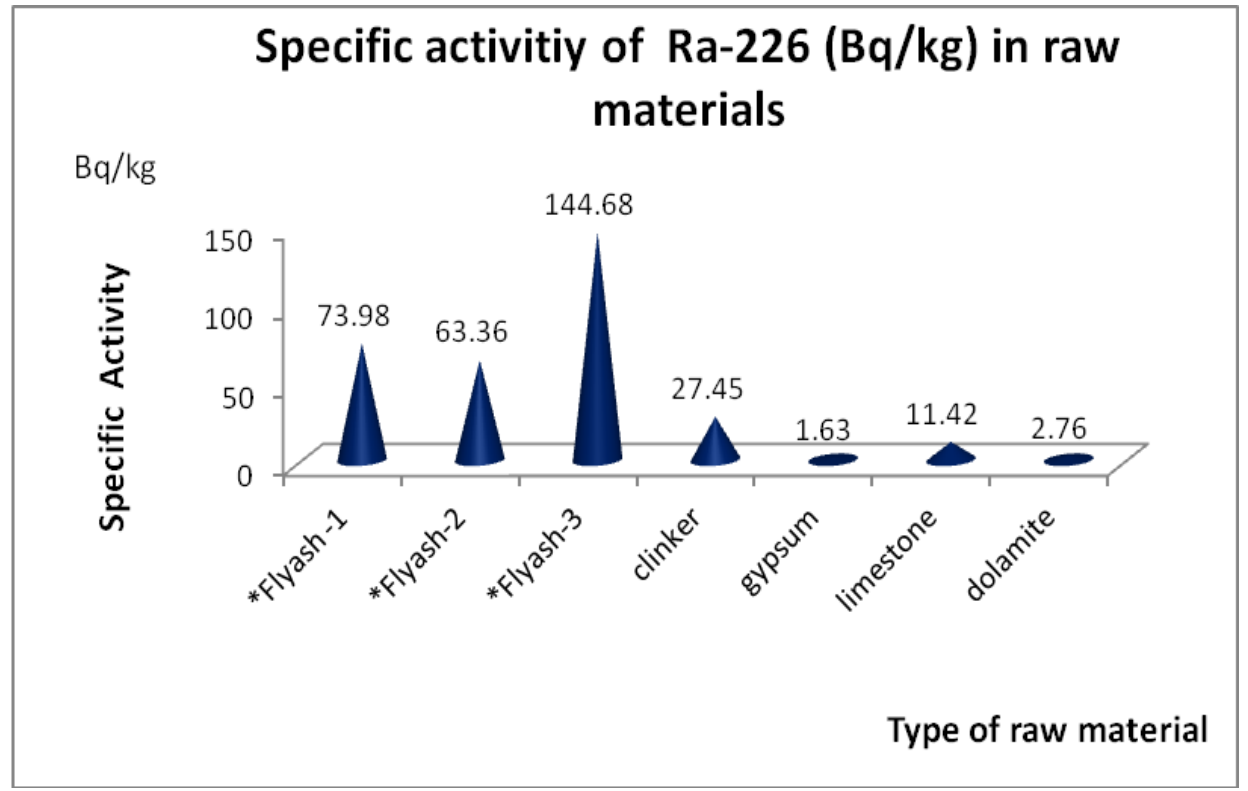

Figure 2: Mean Specific Activities of ${ }^{226} \mathrm{Ra}$ in raw material samples

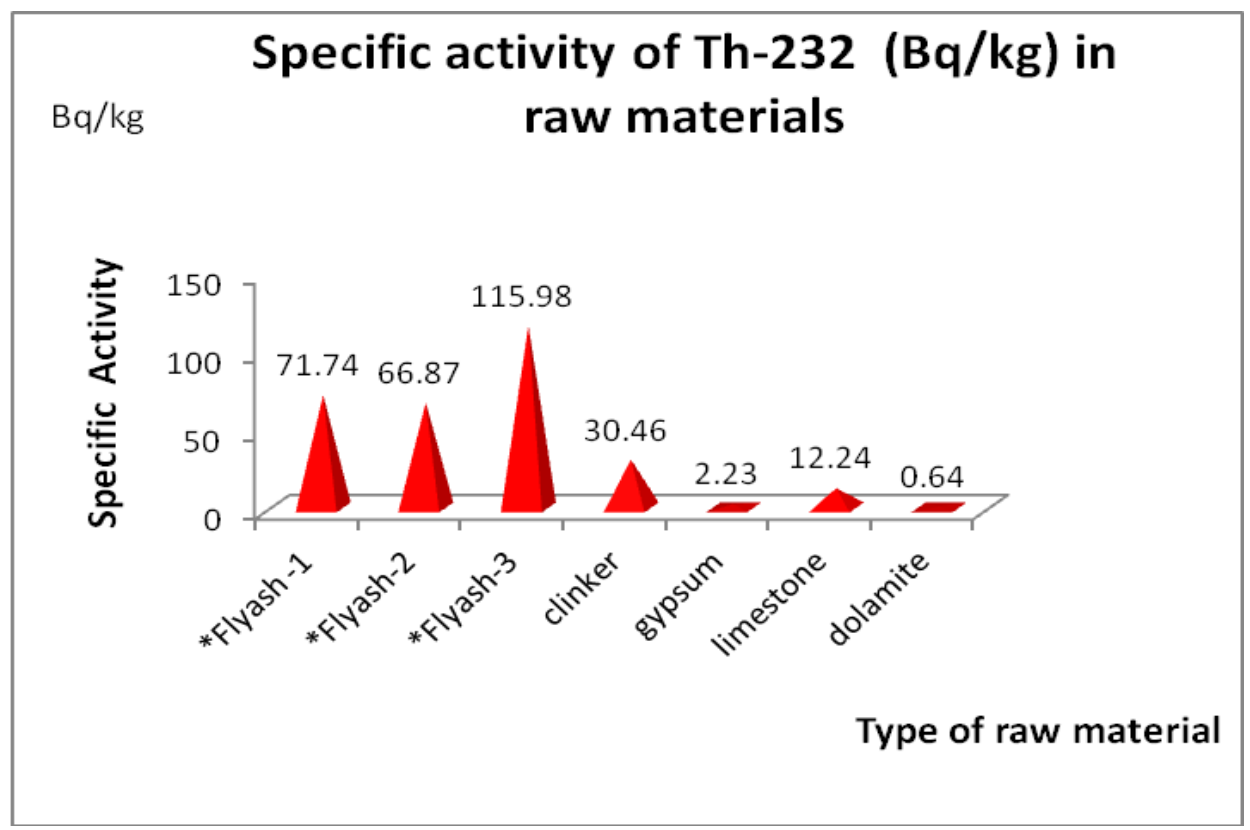

Figure 3: Mean Specific Activities of ${ }^{232} \mathrm{Th}$ in raw material samples 


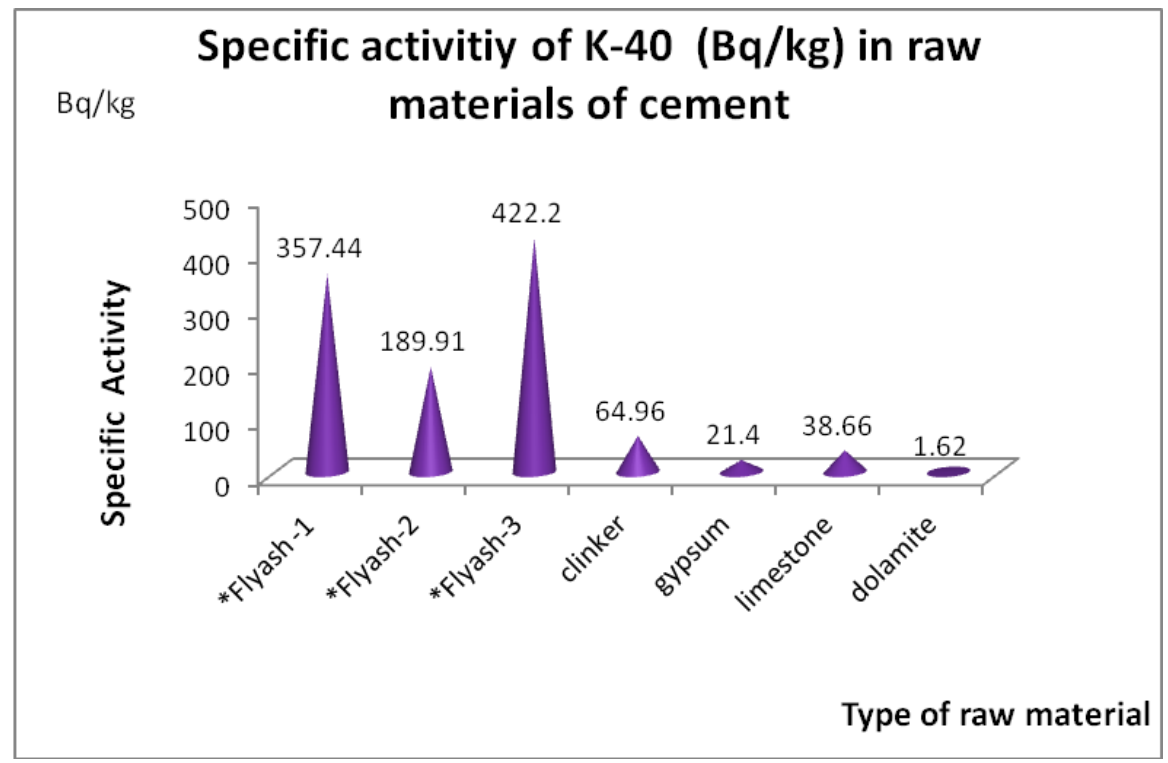

Figure 4: Mean Specific Activities of ${ }^{40} \mathrm{~K}$ in raw material samples

According to the Table 3 and Figures 2, 3 and 4 the highest concentrations of radionuclides was observed in fly ash samples. The concentrations of radionuclides were very low in gypsum and dolomite samples.

The specific activities of ${ }^{226} \mathrm{Ra},{ }^{232} \mathrm{Th}$ and ${ }^{40} \mathrm{~K}$ in $\mathrm{Bq} \mathrm{kg}^{-1}$ obtained for some kinds of raw materials in some countries are shown in Table 4.

Table 4: Comparison of specific activities of the radionuclides in raw materials considered for the present study with those from other countries.

\begin{tabular}{|c|c|c|c|c|c|c|}
\hline Country & $\begin{array}{c}\text { No. of } \\
\text { sampl } \\
\text { es }\end{array}$ & $\begin{array}{c}\text { Raw } \\
\text { material }\end{array}$ & $\begin{array}{c}{ }_{1}^{226} \mathrm{Ra} \\
\mathrm{Bq} \mathrm{kg}-\end{array}$ & $\begin{array}{c}{ }_{1}^{232} \mathrm{Th} \\
\mathrm{Bq} \mathrm{kg}^{-}\end{array}$ & $\begin{array}{c}40 \mathrm{~K} \\
\mathrm{~Bq} \mathrm{~kg}^{-} \\
1\end{array}$ & Reference \\
\hline \multirow[t]{3}{*}{ Denmark } & 7 & gypsum & 10 & 07 & $\mathrm{n} . \mathrm{m}$ & $\begin{array}{l}\text { (UNSCEA } \\
\text { R, 1982) }\end{array}$ \\
\hline & 10 & fly ash & 150 & 90 & n.m & $\begin{array}{l}\text { (UNSCEA } \\
\text { R, 1982) }\end{array}$ \\
\hline & 13 & clinker & 66 & 55 & n.m & $\begin{array}{l}\text { (UNSCEA } \\
\mathrm{R}, 1982 \text { ) }\end{array}$ \\
\hline \multirow[t]{2}{*}{ Italy } & n.m. & $\begin{array}{l}\text { limeston } \\
\text { e }\end{array}$ & 11 & 2 & 22 & $\begin{array}{l}\text { (Rizzo et } \\
\text { al., 2001) }\end{array}$ \\
\hline & n.m. & gypsum & 6.0 & 2.0 & 32 & $\begin{array}{l}\text { (Rizzo et } \\
\text { al., 2001) }\end{array}$ \\
\hline
\end{tabular}




\begin{tabular}{|c|c|c|c|c|c|c|}
\hline \multirow[t]{2}{*}{ Germany } & 23 & gypsum & $\begin{array}{r}< \\
19\end{array}$ & $<11$ & n.m & $\begin{array}{l}\text { (UNSCEA } \\
R, 1982 \text { ) }\end{array}$ \\
\hline & 28 & fly ash & 211 & 130 & n.m. & $\begin{array}{l}\text { (UNSCEA } \\
\mathrm{R}, 1982 \text { ) }\end{array}$ \\
\hline Poland & 106 & fly ash & $\begin{array}{l}63- \\
610\end{array}$ & $\begin{array}{l}33- \\
320\end{array}$ & n.m. & $\begin{array}{l}\text { (UNSCEA } \\
R, 1982 \text { ) }\end{array}$ \\
\hline $\begin{array}{l}\text { United } \\
\text { kingdom }\end{array}$ & 73 & gypsum & 22 & 07 & n.m. & $\begin{array}{l}\text { (UNSCEA } \\
\mathrm{R}, 1982 \text { ) }\end{array}$ \\
\hline \multirow[t]{2}{*}{$\begin{array}{l}\text { Banglade } \\
\text { sh }\end{array}$} & \multirow[t]{2}{*}{ n.m. } & $\begin{array}{l}\text { limeston } \\
\text { e }\end{array}$ & 68 & 107 & 1660 & $\begin{array}{l}\text { (Alam et } \\
\text { al., 1999) }\end{array}$ \\
\hline & & gypsum & 255 & 21.4 & 121 & $\begin{array}{l}\text { Chowdhu } \\
\text { ry et al., }\end{array}$ \\
\hline \multirow[t]{2}{*}{ Egypt } & \multirow[t]{2}{*}{ n.m. } & $\begin{array}{l}\text { limeston } \\
\mathrm{e}\end{array}$ & 20.4 & 4.4 & 19.3 & $\begin{array}{l}\text { (Ahamed } \\
\text { and } \\
\text { Hussein, } \\
\text { 1998) }\end{array}$ \\
\hline & & gypsum & 31.7 & 55 & 89 & $\begin{array}{l}\text { (El- } \\
\text { Taher, }\end{array}$ \\
\hline \multirow[t]{2}{*}{ Brazil } & \multirow[t]{2}{*}{ n.m. } & $\begin{array}{l}\text { limeston } \\
\mathrm{e}\end{array}$ & 24.3 & 7.0 & 205 & $\begin{array}{l}\text { (Malanka } \\
\text { et al., }\end{array}$ \\
\hline & & gypsum & 6.3 & n.d. & 154 & $\begin{array}{l}\text { (Malanka } \\
\text { et al., }\end{array}$ \\
\hline \multirow[t]{2}{*}{$\begin{array}{l}\text { Saudi } \\
\text { Arabia }\end{array}$} & \multirow[t]{2}{*}{ n.m. } & $\begin{array}{l}\text { limeston } \\
\mathrm{e}\end{array}$ & 28.6 & 49.2 & 66 & $\begin{array}{l}\text { (El- } \\
\text { Taher, }\end{array}$ \\
\hline & & gypsum & 33.3 & 47.2 & 88 & $\begin{array}{l}\text { (El- } \\
\text { Taher, }\end{array}$ \\
\hline \multirow[t]{3}{*}{ Turkey } & \multirow[t]{3}{*}{128} & $\begin{array}{l}\text { Limesto } \\
\text { ne }\end{array}$ & 16.5 & 7.7 & 88.1 & $\begin{array}{l}\text { (Turhan, } \\
\text { 2008) }\end{array}$ \\
\hline & & fly ash & $\begin{array}{r}232 . \\
3\end{array}$ & $\begin{array}{r}117 . \\
1\end{array}$ & $\begin{array}{r}466 . \\
2\end{array}$ & $\begin{array}{l}\text { (Turhan, } \\
\text { 2008) }\end{array}$ \\
\hline & & Gypsum & 10.8 & 3.6 & 44.5 & $\begin{array}{l}\text { (Turhan, } \\
\text { 2008) }\end{array}$ \\
\hline \multirow{5}{*}{$\begin{array}{l}\text { Present } \\
\text { study }\end{array}$} & \multirow[t]{5}{*}{30} & fly ash & 94.0 & 84.8 & 323. & \\
\hline & & Gypsum & 1.63 & 2.23 & 21.4 & \\
\hline & & Limesto & 11.4 & 12.2 & 38.6 & \\
\hline & & Clinker & 27.4 & 30.4 & 64.9 & \\
\hline & & Dolomit & 2.76 & 0.64 & 1.62 & \\
\hline
\end{tabular}

(n.m-not calculated; n.d.- not detected)

It can be seen from Table 4, that the radioactivity in raw materials used for manufacturing cement varies from one country to another. 
The values given in this table were not the representative values for the countries mentioned, but they were typical for the regions where samples were collected. Table 4 also shows that specific activity of ${ }^{226} \mathrm{Ra}$ and ${ }^{232} \mathrm{Th}$ in fly ash considered in the present study is lower than those of other countries.

The mean values of specific activities of ${ }^{226} \mathrm{Ra},{ }^{232} \mathrm{Th}$ and ${ }^{40} \mathrm{~K}$ calculated for cement samples for the present study and the corresponding values determined by other countries are shown in Table 5.

Table 5: Comparison of specific activities $\left(\mathrm{Bq} \mathrm{kg}^{-1}\right)$ of radionuclides in Sri Lankan made cement samples with the published data of other countries.

\begin{tabular}{|c|c|c|c|c|c|}
\hline Country & $\begin{array}{c}\text { No.of } \\
\text { sample } \\
\text { s }\end{array}$ & $\begin{array}{c}226 \mathrm{Ra}^{2} \\
\mathrm{~Bq} \mathrm{~kg}^{-1}\end{array}$ & $\begin{array}{c}{ }^{232} \mathrm{Th} \\
\mathrm{Bq} \mathrm{kg}^{-1}\end{array}$ & $\begin{array}{c}40 \mathrm{~K} \\
\mathrm{~Bq} \mathrm{~kg}^{-1}\end{array}$ & Reference \\
\hline Australia & 7 & 51.5 & 48.1 & 114.7 & $\begin{array}{l}\text { (Bereka and } \\
\text { Mathew, }\end{array}$ \\
\hline Austria & 18 & 26.7 & 14.2 & 210.0 & $\begin{array}{l}\text { (Sorantin } \\
\text { and Steger, }\end{array}$ \\
\hline Algeria & 12 & 41.0 & 27.0 & 422.0 & $\begin{array}{l}\text { (Amarani } \\
\text { and Tahtat, }\end{array}$ \\
\hline Bangladesh & 18 & 62.3 & 59.4 & 328.9 & $\begin{array}{l}\text { (Chowdhury } \\
\text { et al., 1998) }\end{array}$ \\
\hline Brazil & 1 & 61.7 & 58.5 & 564.0 & $\begin{array}{l}\text { (Malanka et } \\
\text { al., 1993) }\end{array}$ \\
\hline China & 46 & 56.5 & 36.5 & 173.2 & $\begin{array}{l}\text { (Xinwei., } \\
\text { 2005) }\end{array}$ \\
\hline Egypt & 85 & 78.0 & 33.3 & 37.0 & $\begin{array}{l}\text { (El Afiafi, } \\
2006)\end{array}$ \\
\hline Finland & 11 & 40.0 & 20.0 & 251.0 & $\begin{array}{l}\text { (Mustonen, } \\
1984) .\end{array}$ \\
\hline Ghana & 50 & 35.94 & 25.44 & 233.0 & $\begin{array}{l}\text { (Kpeglo, } \\
\text { 2011) }\end{array}$ \\
\hline Greece & 20 & 62.8 & 23.8 & 284.1 & $\begin{array}{l}\text { (Papastefano } \\
\mathrm{u}, 2005)\end{array}$ \\
\hline India & 1 & 37.0 & 24.1 & 432.2 & $\begin{array}{l}\text { (Kumar, } \\
\text { 1999) }\end{array}$ \\
\hline Italy & 7 & 38.0 & 22.0 & 218.0 & $\begin{array}{l}\text { (Rizzo et al., } \\
\text { 2001) }\end{array}$ \\
\hline
\end{tabular}




\begin{tabular}{|l|r|r|r|r|l|}
\hline Japan & 16 & 35.8 & 20.7 & 139.4 & $\begin{array}{l}\text { (Suzuki et } \\
\text { al., 2000) }\end{array}$ \\
\hline Netherlands & 6 & 27.0 & 19.0 & 230.0 & $\begin{array}{l}\text { (Ackers et } \\
\text { al., 1985) }\end{array}$ \\
\hline Pakistan & 25 & 26.7 & 28.6 & 272.9 & $\begin{array}{l}\text { (Khan and } \\
\text { Khan, 2001) }\end{array}$ \\
\hline Tunisia & 2 & 21.5 & 10.1 & 175.5 & $\begin{array}{l}\text { (Hizem et al. } \\
\text { 2005) }\end{array}$ \\
\hline Turkey & 145 & 40.0 & 28.0 & 248.3 & $\begin{array}{l}\text { (Turhan, } \\
2008) .\end{array}$ \\
\hline Sri Lanka & 65 & 38.5 & 31.8 & 165.0 & \\
\hline
\end{tabular}

According to Table 5 the mean specific activity values for cement samples taken from different countries shows considerable variation. The reason for this is the type and different proportions of raw materials used in cement manufacturing.

\section{Assessment of radiation hazard}

The radiation hazard caused by cement used in Sri Lanka was determined by the radiological parameter, the annual effective dose rate (A.E.D). Table 6 shows the calculated values of this parameter and the absorbed dose rate for the different brands of cement studied.

Table 6: Annual effective dose rates and absorbed dose rates for cement samples.

\begin{tabular}{|l|r|r|}
\hline Type of cement & $\begin{array}{c}\text { Absorbed dose rate in } \\
\text { air }\left(\mathrm{nGy} \mathrm{h}^{-1}\right)\end{array}$ & $\begin{array}{c}\text { A.E.D. } \\
\left(\mathrm{mSv} \mathrm{y}^{-1}\right)\end{array}$ \\
\hline CEM-1 OPC 1 & 45.01 & 0.22 \\
\hline CEM-II PLC & 42.23 & 0.21 \\
\hline CEM-III PPC 1 & 103.85 & 0.51 \\
\hline CEM-IV OPC 2 & 60.57 & 0.30 \\
\hline CEM-V OPC 3 & 53.03 & 0.26 \\
\hline CEM-VI PPC 2 & 58.93 & 0.29 \\
\hline CEM-VII OPC 4 & 60.27 & 0.31 \\
\hline
\end{tabular}




\begin{tabular}{|l|c|c|}
\hline $\begin{array}{l}\text { CEM-VIII Imported } \\
\text { OPC } 1\end{array}$ & 42.23 & 0.21 \\
\hline $\begin{array}{l}\text { CEM-IX Imported } \\
\text { OPC 2 }\end{array}$ & 59.09 & 0.29 \\
\hline $\begin{array}{l}\text { CEM-X Imported OPC } \\
3\end{array}$ & 30.02 & 0.15 \\
\hline $\begin{array}{l}\text { CEM-XI Imported PPC } \\
1\end{array}$ & 79.42 & 0.39 \\
\hline
\end{tabular}

The Annual effective dose inside the reference room considered was calculated by using Equation 7 . The calculated values for different cement samples are shown in Table 6 . The estimated average annual effective dose ranged from 0.15 to $0.51 \mathrm{mSv} \mathrm{y}^{-1}$ and less than the recommended maximum permissible public dose $1.0 \mathrm{mSv}^{-1}$ (International Basic Safety, IAEA, 1996).

\section{Conclusion}

From the results it is evident that there are considerable variations in the specific activities of radionuclides ${ }^{226} \mathrm{Ra},{ }^{232} \mathrm{Th}$ and ${ }^{40} \mathrm{~K}$ in raw materials. The highest concentrations of these radionuclides were observed in fly ash.

The concentrations of radionuclides in the samples of different brands of cement were not same. The highest values of ${ }^{226} \mathrm{Ra}$ and 232Th were observed in CEM-III PPC-1 cement where $25 \%$ fly ash was added, whereas the minimum values of ${ }^{226} \mathrm{Ra},{ }^{232} \mathrm{Th}$ and ${ }^{40} \mathrm{~K}$ were in CEM -X imported OPC 3 cement. The highest concentration of ${ }^{40} \mathrm{~K}$ was observed in CEM-V OPC 3 cement. These variations are due to the varying amounts of ${ }^{238} \mathrm{U},{ }^{232} \mathrm{Th}$ and ${ }^{40} \mathrm{~K}$ in the raw materials and different proportions of the raw materials used in manufacturing different brands.

It was observed that the annual effective dose values for all the studied samples were lower than the recommended maximum permissible public dose of $1.0 \mathrm{mSv}^{-1}$. All the cement samples studied did not show any significant radiation hazard and could be considered safe for construction work. 


\section{Acknowledgments}

The authors would like to acknowledge The Open University of Sri Lanka for providing research grants to carry out this work.

\section{References}

Ackers, J. G., DenBoer, J. F., Delong, P. \& Wolschrijn, R. A. (1985). Radioactivity and radon exhalation rates of building materials in the Netherlands. Science Total Environment 45:151-156. https://doi.org/10.1016/0048-9697(85)90215-3

Ahamed, N. \& Hussein, A. (1998).Natural radioactivity in Gordanian soil and building materials and the associated radiation hazards. Journal of Environmental Radioactivity 39: 9 -22. https://doi.org/10.1016/S0265-931X(97)00046-5

Alam, M. N., Chowdhury, M. I., Kamal, M., Ghose, S., Islam, M. N., Mustata, M. N., Miah, M. H. \& Ansary, M. M. (1999). The ${ }^{226} \mathrm{Ra},{ }^{232} \mathrm{Th}$ and ${ }^{40} \mathrm{~K}$ activities in beach sand minerals and beach soil of Cox, s Bazar, Bangladesh. Journal of Environmental Radioactivity 46:243-250.

https://doi.org/10.1016/S0265-931X(98)00143-X

Amarani, D. \& Tahtat, M. (2001). Natural radioactivity in Algerian building materials. Applied Radiation Isotopes 54:687-689. https://doi.org/10.1016/S0969-8043(00)00304-3

Bereka, J. \& Mathew, P. J. (1985). Natural radioactivity of Australian building materials, Industrial wastes and by-products. Health Physics 48:87-95. DOI: 10.1097/00004032-19850100000007.

Chowdhury, L. M., Alam, M. N. \& Ahmed, A. K. S. (1998). Concentration of radionuclides in building and ceramic materials of Bangladesh and evaluation of radiation hazard. Journal of Radioanlytical Nuclear Chemistry 231(1-2):117122. https:// doi.org/10.1007/BF02388016 
Curie, L. A. (1968). Limits of qualitative determination and quantitative determination. Analytical Chemistry 40 (3):586593.

El Afiafi, E. M, Hilal, M. A, Khalifa, S. M. \& Aly, H. F. (2006). Evaluation of $\mathrm{U}$, Th and $\mathrm{K}$ and emanated radon in some NORM and TENORM samples. Radiation Measurements 41:627-633. https://doi.org/10.1016/j.radmeas.2005.09.014

El-Taher, A. (2010). Gamma spectroscopic analysis and associated adiation hazards of building materials used in Egypt. Radiation Protection Dosimetry 138 (2):166-173. https://doi.org/10.1093/rpd/ncp205

El-Taher, A. (2012). Assessment of natural radioactivity levels and radiation hazards for building materials used in Qassim area, Saudi Arabia. Rom. Journal of Physics; 57:726-735.

Hizem, N., Fredj, A. B. \& Ghedira, I. (2005). Determination of natural radioactivity in building materials used in Tunisian dwellings by gamma ray spectrometry. Radiation Protection Dosimitry 114: 533-537. https://doi.org/10.1093/rpd/nch489

Interim report on potential consequences for the Dutch population of using waste substances with an enhanced concentration of radionuclides as building materials for houses by Health Council of the Netherlands (1985). The Hague, The Netherlands.

International Basic Safety Standards for Protection against Ionizing Radiation and for the Safety of Radiation Sources-Schedule II, International Atomic Energy Agency (IAEA) (1996).

Khan, K. \& Khan, H. M. (2001). Natural gamma emiting radionuclides in Pakistani Portland cement. Applied Radiation Isotopes 54:861-865.

https://doi.org/10.1016/S0969-8043(00)00327-4

. Kpeglo, D. O., Lawluvi, H., Faanu, A., Awudu, A. R., Deatanyah, P., Wotorchi, S. G., Arwui, C. C., Emi- Reynolds, G. \& Darko, E. O. (2011). Natural radioactivity and its associated hazard in 
Ghanaian cement. Journal of Environment and Earth Sciences 3(2):160-166.

Kumar, V., Ramachandran, T. V. \& Prasad, R. (1999). Natural radioactivity of Indian building materials and by-products. Applied Radiation Isotopes 51:93-96. https://doi.org/10.1016/S0969-8043(98)00154-7

Malanka, A., Pessina, V., Dallara, G., Luce, C. N. \& Gaidol, L. (1993). Natural radioactivity in building materials from the Brazilian state of Espirito Santo. Applied Radiation Isotopes 46:13871392. https://doi.org/10.1016/0969-8043(95)00223-Z

Mustonen, R. (1984). Natural radioactivity and radon exhalation rate from finish building materials. Health Physics 46:1195-1203. DOI: 10.1097/00004032-198406000-00003

Papastefanou, C., Stoulos, S. \& Manolopoulou, M. (2005). The radioactivity of building materials. Journal of Radioanalytical Nuclear Chemistry 266(3):367-372.

Report to the General Assembly of the United Nations. Annex C. Ionizing Radiation, Sources and Biological Effects. United Nations Scientific Committee on the Effects of Atomic Radiation (UNSCEAR). (1982). United Nations Sales Publications (NY. USA).

Report to the General Assembly of the United Nations, Annex C, Ionizing Radiation, Sources and Biological Effects. United Nations Scientific Committee on the Effects of Atomic Radiation (UNSCEAR). (1993). United Nations Sales Publications. (NY, USA).

Report to the General Assembly of the United Nations, Annex B, Exposures of the public and workers from various sources of radiation. United Nations Scientific Committee on the Effects of Atomic Radiation (UNSCEAR). (2008). United Nations Sales Publications. (NY, USA).

Rizzo, S., Brai, M., Basile, S., Bellia, S. \& Hauser, S. (2001). Gamma activity and geochemical features of building materials: 
estimation of gamma dose rate and indoor radon levels in Sicily. Applied Radiation Isotopes 55:259-265.

https://doi.org/10.1016/S0969-8043(00)00384-5

Sorantin, P. \& Steger, F. (1984). Natural radioactivity of building materials in Austria. Radiation Protection Dosimetry 7:59-61. https://doi.org/10.1093/oxfordjournals.rpd.a082963

Suzuki, A., Lida, T., Moriizumi, J. \& Sakuma, Y. (2000). The effects of different types of concrete on population doses. Radiation Protection Dosimetry 90:437-443. https://doi.org/10.1093/oxfordjournals.rpd.a033171

Topping, J. (1972). Errors of Observations and Their Treatment. New York, Halsted Press.

Turhan, S. (2008). Assessment of the natural radioactivity and radiological hazard in Turkish cement and its raw materials. Journal of Environmental Radioactivity 99:404--414 https://doi.org/10.1016/j.jenvrad.2007.11.001

Xinwei, L. (2005). Radioactive analyses of cement and its products collected from Shannxi China. Health Physics 88:84-86. https:// doi: 10.1097/01.HP.0000142498.08451.c8 